\title{
Tyolet and the Marginalization of the Romance Feminine
}

\section{Ross G. Arthur}

\author{
York University
}

$L$

ike many another medieval adventure romance and Breton lai, Tyolet closes by leaving the young man in its audience contemplating the attractive prospects of a brave but landless hero, much like himself, married to a well-endowed heiress. This final picture is preceded by a narrative which, by its very sequential organization, veils the contradictions in such a situation. The young man of the story is left exercising dominion over a woman's territories, dispensing her wealth to her followers in order to ensure that they will be loyal to him: his independence is dependent on her. In order to conceal the fact that these circumstances are problematic, to say the least, this final situation must be presented as a result, especially as a result of vigorous masculine striving, and not a simple consequence of a female's gift. The active participation of the wife and of all the other female characters in the poem must be severely restricted, at least by allotting to them only secondary adjuvant functions (nurturing, supporting, inspiring) if the hero is to be able to fulfil his role as identification-model for the hopeful young men in the audience.

So much might be said about dozens of surviving texts in all the major western European languages, which repeat such attempts to resolve the unresolvable contradiction so obsessively as to constitute a collective confession of failure: what sets Tyolet apart is its set of choices made from the range of subsidiary techniques for diminishing audience awareness of the crucial role that the wife and other females play in the narrative events which construct the circumstances that allow the hero's escape from the life of a dependent knight. One of the most common approaches is to begin by distributing the various stock feminine functions among a number of female characters: Erec et Enide is unusual in its close attention to one woman, where Yvain shares out the roles that Enide plays among Lunete, Laudine, la Dame de Noroison, the pucele with the ointment, the captive sempstresses and even, mutatis mutandis, the lion. In Tyolet, the traditional romance feminine is parcelled out to four characters, the hero's mother, a forest fairy, the daughter of the King of Logres, and a pucele riding the obligatory mule who shows up unexpectedly near the end of the poem (551-2). Each of these women plays an essential role in the hero's progression toward established seniority, but three different strategies are employed to direct audience attention away from them and toward masculine chivalric and professional skills which are thereby made to seem primary. First, the author creates them in such a way that they are motivated only by the desires of others. Second, their actions are not provided with 
any consistent underlying unity, but are left as a set of incoherent deeds. Finally, each separate female action is immediately followed by a masculine deed which suggests that the "true" cause of the ensuing result was in fact something manly.

The poem's opening episode (37-276) describes the childhood life of the hero. His father was a knight who died fifteen years before the action commences, and Tyolet has been raised in the forest with only his mother for a companion. As a consequence, Tyolet remains totally ignorant of knighthood: this is revealed to the audience through a quasi-catechetical conversation between the youth and the first knight he ever sees. "What is that thing on your head?" he says, "what is that long piece of wood that you carry?" he inquires, when he sees the knight's helmet and lance.

Since nearly every modern reader who comes to Tyolet is already a reader of Chrétien de Troyes, this episode has been baptized a reflex of "the Perceval-motif." The contrasts in detail, however, are as striking as the similarities between the two general situations. Perceval, for example, activates a human/angel dichotomy as the young man attributes supernatural status to the knight on account of his beauty, while Tyolet establishes a human/animal split, as the youth asks "what sort of beast a knight is," (137) and the knight himself says that a knight is a "very dreaded beast which captures and eats other beasts" (141-2). This knight is soon joined by two hundred others, who have been engaged in a stark military campaign for which no motive, just or unjust, is given: "They had carried out the king's orders: they had captured a stronghold and put it to the torch, reducing it to ashes" (200-03). Perceval would be one of the angels; Tyolet wishes to be a chevalier-beste, and identifies himself as such to King Arthur when he arrives at court (245).

The contrasts between the mother-roles in the two poems arise not from such logical oppositions but from the systematic diminution and containment of female influence in Tyolet. This mother, unlike Perceval's, does not keep her son ignorant of knighthood as part of any systematic plan to keep him from following her husband into danger and death; his lack of knowledge is simply a by-product of his isolation. Her resistance appears only later, when he announce his wish to become a knight, and is based rather on the cruelty of the profession. She is upset that he has "seen a beast like this which takes and eats others" (255-6).

Even this weakened version of smothering control is further contained by the fact that the Knight-Beast knew in advance that this would be her response, prepared Tyolet to meet it, gave him advice about how to overcome it and prophesied accurately how she would finally act if he stood up to her:

E ele te dira briement que ce li poise molt forment que tu as tel beste veüe, que autre engingne et autre tue.

E tu li dis que par ta foi, 
que male joie avra de toi

se tu ne puez estre tel beste

e tel coiffe avoir en ta teste;

e des ce qu'ele ce orra,

isnelement $t^{\prime}$ aportera

toute autretele vesteüre,

cote e mantel, coiffe e ceinture,

e chauces e lonc fust plané,

tex con tu as ci esgardé. (233-46)

She will tell you immediately that she is sorry that you have seen the beast that preys upon others and kills them. And you tell her, by your faith, that she will find no joy in you if you cannot be such a beast and have such a headpiece on your head. And as soon as she hears this, at once she will bring you a completely new outfit - a tunic and a mantle, a helmet and a belt, greaves and a long flat piece of wood, just like these you have seen here.

Forewarned is forearmed, and Tyolet's petulant threat ("if I cannot be such a beast...you will be unhappy on my account," 258-60) has the predicted result. His mother grants him arms: not the fool's motley which serves as a visible sign of Perceval's mother's continuing attempts to sequester him, but the proper panoply which had belonged to the hero's father.

She also provides him with some words of advice, although nothing quite so specific and functional as Perceval receives. She tells him to avoid the companionship of men and women of inferior rank (272-4). Tyolet never recalls these parting words, or, for that matter, the woman who gave them, but the subsequent events reveal that the advice concerning women is simply irrelevant and the advice concerning men is wrong, although not wrong in such a way as to require Tyolet to make any significant effort to correct it. The only woman to whom Tyolet might even be tempted to pay court is the daughter of the King and Queen of Logres, an heiress of higher status than those customarily proffered to romance knights. Among men, the text's operative dichotomy is moral, not social: Tyolet later suffers because of an act of friendship toward a wicked knight - not a villain or a borgois - who tries to claim the fruits of Tyolet's actions as his own; he profits, in turn, from the true companionship of Gauvain, who helps the wounded hero not because he is nobly born but simply because he is noble. In the forest world of Tyolet's childhood, a mother's attempts at control are easily comprehended and circumvented by masculine knowledge and action; in the "real" world of chivalric adventure, a mother's words are totally ineffective.

The second female character who "arms" Tyolet in advance for his encounters with the world is an unnamed fairy who gives him a special gift while he is still a child: if he wants to capture game, all he needs to do is whistle, and every wild beast will be 
paralysed in front of him. The poet is quite insistent on the efficacy of this gift: "God never made any beast that Tyolet could not capture by whistling" (47-8); "There is not a beast in the woods that I do not know, and I capture them all without any trouble" (151-2). We see this power in action, early in the poem, when "He stopped and whistled, and the roebuck came toward him. Tyolet put out his hand and killed the beast" (101-3). This gift is essential to Tyolet's fulfilment of the poem's central adventure, in which he is required to bring to the daughter of the King of Logres the foot of a white stag. After crossing the perilous river, he whistles, the stag comes up to him, and he cuts off its foot (452-60). Given that this beast is guarded by seven lions who maul Tyolet severely after he has taken the beast, it seems reasonable to assume that he would not have succeeded in his task without the gift of the beneficent fairy.

Despite the crucial role she plays in the unfolding action, this fairy receives scant attention from the poet. She does not appear on stage and is given no personality and no motives for her gift. Even her action, the granting of this power, is set back in the past, added as an afterthought to the statement that Tyolet possessed it:
... du vallet bel e engingnos,
hardi e fier e coragos.
Tyolet estoit appelez,
de bestes prendre sot assez
que par son sisflé les prenoit,
totes les bestes qu'il voloit.
Une fee ce li ora
e a siffler li enseigna. (39-46)

\begin{abstract}
(... a fine and clever young man, hardy bold and courageous. Tyolet was his name, and he was very good at capturing beasts; by whistling he would catch all the beasts that he wanted. A fairy had given him this gift, and taught him how to whistle.)
\end{abstract}

The origin of the talent is never mentioned again, although the hero's use of it permeates the tale; once the man has the power, its source in a female's gift becomes irrelevant.

What is more, the whistling power itself is subject to severe limitations. The first description of its use, even before the roebuck scene, shows its failure. After a whole day of hunting without seeing any animals at all, Tyolet spots a large and meaty stag, and whistles: "The stag heard him and looked, but paid him no attention and just went away" (89-90). This is, of course, no ordinary stag. Watching from the other side of the river, Tyolet sees it transform itself into a knight, the "Knight-Beast" who gives him his first lessons in the manly arts. Part of Tyolet's astonishment at such a beast is the fact that he is unable to capture it ( $145 \mathrm{ff}$.), and the audience is left more aware that 
there are certain sorts of creatures immune to the power of the fairy's gift.

This pattern is replicated in Tyolet's encounter with the white stag. True, is it because of the whistle that Tyolet is able to paralyse the stag and remove its foot, but the preliminaries-which occupy considerably more verses-create admiration for the hero for just being in the region where the sought-for beast dwells. Before Tyolet is granted the quest, we hear the full story of the attempt of Lodoer (371-408) who-like an unnamed, unnumbered host of other knights after him (409-14)-is too frightened by the perils of a menacing river to cross into the meadow where the stag lives. More important, perhaps, is the poem's insistence that the fairy's gift may be of use against the stag, but only against the stag: Tyolet whistles, and the stag submits to his knife; the seven lions are quite a different matter. They attack the man who has mutilated their charge, and the scene ends with a picture of a young man who, though severely mauled, is able to kill all seven of the ferocious beasts. In the shuffle, the whistle is forgotten.

As if this were not enough to ensure that Tyolet's transition from knight to king should be seen as dependent on masculine activities, the story goes on to describe how he loses the foot to an unnamed passing knight, who accepts it as a gift and then tries to kill the giver to ensure his own success with the princess. The foot must be rewon, this time not through any skills of female origin. Tyolet is rescued by Gauvain and nursed back to health; the villainous knight has made his claim to the princess, since he is capable of fulfilling the letter of the covenant (363) devised between Arthur and the maiden, that she will marry only the man who gives her the foot. Tyolet arrives in time to challenge the knight's right to the marriage, to assert that he has fulfilled the spirit of the contract by being brave enough to cut the foot, and to support his position by offering to meet him in judicial combat (675-8). The poem's closure in marriage follows immediately (and, it would seem, logically) from Tyolet's success in this masculine competition and his readiness to grant mercy to the now-repentant knight.

The duplicity of the poem's strategies comes to seem almost obsessive: it asserts over and over that women play a determining role at every stage in the hero's progress, but then follows through with a replacing insistence on masculine activities: hunting, crossing dangerous rivers, battling wild animals, manipulating legal procedures and triumphing in peer group competition. The strife between the two competing loci for the powers of preservation and advancement of young manhood is perhaps nowhere more evident than in the scene just following the arrival of the villainous knight at Arthur's court. Gauvain, suspicious because Tyolet has not returned, follows the princess' dog to the meadow where he finds Tyolet, who tells him the whole story. Immediately, fortuitously-how did she cross the perilous river?-a beautiful damsel arrives:

Atant es vos une pucele

sor une mule, gente e bele.

Gauvain gentement salua, 
e Gauvains bien rendu li a,

e puis l'a a soi apelee

estroitement l'a acolee,

si li prie molt doucement

e molt tres amiablement

qu'ele portast cel chevalier

qui molt par fesoit a proisier ...(551-60)

(Then a gentle, beautiful maiden arrived, riding on a mule. She graciously greeted Gauvain, and he returned her greeting. He called her to his side and embraced her, holding her tightly. He asked her very gently and lovingly to take this knight, who had done such fine deeds ...)

Such damsels arrive opportunely in a number of medieval romances. There is one who shows up when Yvain is lying naked in the woods, maddened and degraded to the status of a beast; she anoints him with ointment ( $2960 \mathrm{ff}$.) and initiates his upward path to a knighthood of higher honor than he displayed before his fall. In Les Merveilles de Rigomer, Lancelot lies close to death after a battle with a panther; suddenly there arrives a beautiful lady on a pure white horse, who smears his body with ointment which heals his wounds in an instant and earns her the reverence of all present:

Cil qui la sont, s'en esmervellent,

Basement dient et consellent:

«Cist est garis a poi de paine!

C'est ci Marie Madeleine

S'a aporté de l'ongement

Dont ele fist a Diu present."

Auquant jurent Saint Bertemiu:

«Ains est la biele mere Diu,

Car autre n'en pëust finer.» (16997-17004)

(Everyone present was astonished and they whispered to one another, "He has gotten himself cured painlessly! The lady who brought him that ointment must be Mary Magdalene! She used the same cream on him that she gave as a present to God!" Some others swore by Saint Bertemiu, "She has to be the beautiful mother of God, for no one else could bring about such results.) [Vesce 362]

Any expectations that the Tyolet-maiden will exercise similar and similarly admirable skills vanish, however, in the continuation of Gauvain's request: 


\section{si li prie molt doucement \\ e molt tres amiablement \\ qu'ele portast cel chevalier \\ qui molt par fesoit a proisier, \\ a la noire montaingne au miere. \\ E cele a fete sa proiere, (557-62)}

(He asked her very gently and lovingly to take this knight, who had done such fine deeds, to the doctor of the Black Mountain. And she did as he asked.)

The result is that it is this medical professional - le miere and not la pucele - who heals Tyolet, and he does so simply by cleansing his bloody wounds (569-70) and prescribing a month's bed-rest (574); no instant ointment and nothing smacking of the miraculous.

The world inhabited by Tyolet, then, the world portrayed to the audience as at least analogous to the one through which they hope to progress, contains female characters who attempt to ensure that the young man's career will be advanced by techniques and in accordance with attitudes independent of masculine rule-governed conventions. By the end of the sequence of events, however, their strategies come to seem only a random collection of disparate and uncoordinated actions. In contrast, the apparently fortuitous combination of a different set of cultural forces is presented as resulting in a coherent progression quite in keeping with an idealizing view of masculine motivation. The role played by the absent father, by the Knight-Beast, by King Arthur, by Lodoer and the other knights of the Round Table, by Gauvain and even by the villainous knight, all contribute to the establishment of Tyolet, in the eyes of the audience and in the eyes of all the poem's characters, as a totally successful young man, a knight worthy of being a king, a king who will function independently of feminine influence despite the feminine origin of his material well-being.

At this point, a critical question arises, not, perhaps, in the voice of a professional academic, but from a student: Why, if he pushes all the women and all their actions aside like that, does the poet bother to include them at all? That, of course, is the whole point, part of the reason why the poem was composed and part of the reason why there are so many romances and Breton lais which all, in varying degrees and with various devices, do the same thing. These texts are the record of an oft-repeated conversation between the members of a historically-defined class of men, some of whom fought battles, some of whom wrote poems, some of whom, for that matter, wrote philosophy and delivered sermons. All of their individual desires and motivations are, in reality, mediated and subsumed by the desires of another, a lord or the Lord, and everything they do is first and foremost done in the service of that other. The burden that this situation imposes on them needs to be alleviated; this is done most effectively by their 
own mutual reassurances - endlessly repeated as all lies must be - that the situation is merely temporary and will be ended by a well-deserved translation into another sphere of activity. This romantic text, and all the others which share its concerns, says, repeatedly, "We may be in a situation of powerlessness, in which all that we do, from writing poetry through to risking our lives in battle, is done for the benefit of a master. But it could be worse. We could be isolated from each other, with no sense of a community and no governing providential plan to ensure our escape. We could be stuck here permanently. We could be women."

\section{Works Consulted}

Chrétien de Troyes. Le Chevalier au lion (Yvain). Ed. Mario Roques. Paris: Honoré Champion, 1952.

Chrétien de Troyes. Le Conte du Graal (Perceval). Ed. Félix Lecoy. Paris: Honoré Champion, 1972.

Chrétien de Troyes. Erec et Enide. Ed. Mario Roques. Paris: Honoré Champion, 1952.

Jehan. The Marvels of Rigomer. Tr. Thomas Vesce. Garland: New York, 1988.

Jehan. Les Merveilles de Rigomer. Ed. Wendelin Foerster. Dresden: Gesellschaft für Romanische Literatur, 1908.

Tyolet. In Les Lais anonymes des XIle et XIIIe siècles. Ed. Prudence Mary O'Hara Tobin. Geneva: Droz, 1976. 